\title{
WESTERN AND JAPANESE CONSTITUTIONAL THOUGHT IN THE SHAPING OF THE ROLE OF THE JAPANESE EMPEROR IN THE 1889 AND 1946 CONSTITUTIONS
}

\author{
Elisa Bertolini \\ Bocconi University
}

\begin{abstract}
CONTENT: I. PREMISE. - II. THE EMPEROR: SYMBOL OR RULER? - III. THE MEIJI ERA: A CONSTITUTIONAL FRAMEWORK FOR THE EMPEROR. - 3.1. Kido Koin's constitutional draft. - 3.2. The Genrōin draft. - 3.3. The Oligarchs' memoranda. - 3.4. Itō meets the Germans. - 3.5. The Meiji Constitution. - 3.6. Interpreting the Meiji Constitution and the Tennōsei Fashizumu. - IV. FROM HEAVEN TO EARTH: A NEW CONSTITUTION FOR A NEW EMPEROR. - V. CONCLUSION: AN EMPEROR FOR THE TWENTY-FIRST CENTURY.
\end{abstract}

\begin{abstract}
The article deals with the combined influence of the Japanese and the Western traditions and legal thoughts in the shaping of the imperial institution in the two Japanese Constitutions, the 1889 Meiji Constitution and the 1946 "American" Constitution. The Meiji Constitution, modelled after the 1850 Constitution of Prussia, enshrines the sacred and eternal characters of the imperial system, within a Western framework; while the 1946 Constitution completely alters the imperial system, modifying the sovereignty principle and assigning a mere symbolic role to the Emperor.
\end{abstract}

Keywords: Sovereignty principle, imperial system, constitutional amendment, legal transplant

\section{PREMISE}

Japan is a country with a thousand-year old tradition and whose monarchy is considered almost eternal, being unbroken since $660 \mathrm{BC}$. However, the country's constitutional system is quite young with respect to the Western ones. Japan now belongs to the category of democratic-pluralistic State within the Western legal tradition, but that is the result of a quick and astonishing twentyyear period of modernisation that took place at the end of the nineteenth century, the so-called "Westernisation", and of the seven-year occupation period in the aftermath of the Second World War.

These two "encounters" with Western counterparts marked two pivotal moments in the history of the country. They were both moments of deep political crisis, despite of a different nature, and both far from voluntary.

The twenty-first century "Westernisation" - the first encounter - followed the forced confront with the Western powers that wanted free trade with Japan. The contact with these foreign nations abruptly revealed the gap between them and Japan, whose policy of centuries of isolation had made the country inadequate to

Names appearing in the paper (Japanese authors in footnotes too) are given in the usual Japanese order, that is with the surname first. 
have an equal confront at international level. While Western countries had evolved their institutional, social and economic structure, also thank to the reciprocate contacts they had, Japan voluntarily kept out from any contact whatsoever, thus perpetuating a feudal institutional, social and economic model. Therefore, Japan was imposed the unequal treaties by the major Western countries and it was the feeling of being at the mercy of foreign countries that that triggered the modernisation. The Western powers became at the same time foes to fight (in order to get the unequal treaties renegotiated) and a model to look upon.

Japan opened to Western knowledge in every possible area, thus undergoing a massive and successful transformation, without betraying her core cultural and traditional identity.

The second encounter was much more traumatic, since it resulted from the atomic disaster of the Second World War. Therefore, the political and economic situation the country was in was substantially different with respect to the one of eighty-ninety years earlier and this time the foreign influence affected the real core of the Japanese institutions.

While the nineteenth century legal transplant was guided by the Japanese government and performed in accordance to the Japanese cultural identity, the one of the twentieth century was coerced, with a very narrow room for the Japanese government to act, and far less respectful of the country cultural tradition.

Despite this significant difference of the two transplants, the Japanese experience has undoubtedly been a success, not just when considering the adoption of foreign institutions and legal concepts, but also for the capability of the Japanese society to "Japanise" this Western wave as much as she could. This is more difficult if one considers the substantial cultural difference forming the basis of Western and Japanese societies. Surely, this does not close the debate, which is still ongoing on the effective extent of acceptance of these foreign concepts, which according to many scholars is still very low - the preferences for extra-judicial conflict resolution ${ }^{1}$ and for collective rights over individual rights ${ }^{2}$ continue to be the most used arguments - but none can deny that there has been

1 There is abundance of literature on the topic. See, ex multis, Kawashima Takeyoshi, "Dispute Resolution in Contemporary Japan”, in Arthur T. von Mehren (ed.), Law in Japan: The Legal Order in a Changing Society, Harvard University Press, Cambridge, 1963, pp. 41-72; Michael K. Young, "Judicial Review of Administrative Guidance: Governmentally Encouraged Consensual Dispute Resolution in Japan", Columbia Law Review, vol. 84, n 4, 1984, pp. 923-983; J.W.S. Davis, Dispute Resolution in Japan, Kluwer Law International, The Hague, 1996.

2 See, in particular Eric A. Feldman, The Ritual of Rights in Japan, Cambridge University Press, Cambridge, 2000 and John M. Maki, "The Constitution of Japan: Pacifism, Popular Sovereignty, and Fundamental Human Rights”, in Percy R. Luney Jr. and Takahashi Kazuyuki (eds.), Japanese Constitutional Law, University of Tōkyō Press, Tōkyō, 1993, pp. 39-56. For further readings, see Ardath W. Burks, “Japan: The Bellwether of East Asian Human Rights?”, in James C. Hsiung (ed.), Human Rights in East Asia: A Cultural Perspective, Paragon House Publishers, New York, 1985, pp. 31-53; Christina M. Cerna, "Universality of Human Rights and Cultural Diversity: Implementation of Human Rights in Different Socio-Cultural Context”, Human Rights Quarterly, vol. 16, n 4, 1994, pp. 740-752 and Michael C. Davis, "Constitutionalism and Political Culture; the debate over Human Rights and Asian Values”, Harvard Human Rights Journal, vol. 11, 1998, pp. 109-147. 
a remarkable framing of certain pillars of the Japanese tradition within a Western framework.

From a legal perspective, both Westernisations - although the second is more an "Americanisation" - affected all the branches of law, but for what concerns the present paper, the analysis will be focused just on the imperial institution, the very heart of Japan and one of the pillars of the country's cultural identity. The imperial institution is a suitable example since her constitutional shaping has been highly debated while drafting both the 1889 and the 1946 Kenpō (Constitution-憲法) and severely affected by the Western influence.

What is interesting is the fact that, although the imperial institution has undergone significant changes - in 1946 mainly - has been maintained as pillar of the whole system, thus giving a sense of continuity, despite the two transplants.

The paper aims at showing how and to what extent foreign legal thought has influenced the shaping of the contemporary imperial institution, while trying to preserve the cultural values embodied in the Emperor. A closer examination will be provided for the Meiji Emperor, as he emerged from the Meiji Constitution of 1889, since the doctrinal debate was livelier and featured a more significant involvement of the Japanese counterpart. On the contrary, the constitutional debate on the Emperor's role in 1945-1946 was unilateral, since Japan, a defeated country, had to bow to the Allied requests, i.e. the necessity of democracy.

\section{THE EMPEROR: SYMBOL OR RULER?}

In order to understand the influence that the Western legal thought has exercised in the shaping of the present-day imperial institution, it is convenient to outline the traditional distinguishing features related to the Japanese monarchy.

Among the various differences that is possible to outline between Western and Eastern monarchies, the Japanese one is so very peculiar due to her being divine and unbroken for ages eternal. The divine character may seem to be similar to the claim of absolute monarchs to be chosen by god, but indeed, there is a significant difference, since the Japanese Emperor is actually a living god. Whereas, the claim to be unbroken for ages eternal is related to the fact that the origins of the Imperial Family are so far away in time that flow into a mythical age. This feature is strengthened by the fact that one single family has ascended the Japanese Imperial Throne and that no surname is connected to that family. Therefore, it is certainly true that the Japanese monarchy is unbroken for ages, despite the qualification of eternal may still be contested. The same goes for the divine origin, which clearly has no historical foundation. As previously outlined, the origin of the monarchy can be traced back more in the myth rather than in history.

Indeed, the history of the Japanese monarchy is provided for by two chronicles: the Kojiki (Records of Ancient Matters-古事記) ${ }^{3}$ and the Nihon Shoki (The

3 The best English translation is still considered the one of Basil H. Chamberlain of 1883 (which was also the first English translation), which is still available by different publishing houses. A more recent translation, that provides also for the etymological interpretations of names 
Chronicles of Japan-日本書記), ${ }^{4}$ written in 711-712 and 720 CE. Both chronicles identify as the first emperor (Tennō-天皇, heavenly sovereign) of Japan Jinmu, a descendant of the Sun Goddess Amaterasu Ōmikami. The Nihon Shoki even gives the dates of his reign as 660-585 BC, thus setting the founding day (建国記念の日) of the Japanese Empire on the $11^{\text {th }}$ February 660 BC. ${ }^{5}$

Since the seventh century, before the writing of both the Kojiki and the Nihon Shoki, the divine character of the Emperor has been emphasised. Emperor Kogyoku stated in $647 \mathrm{CE}$ "Our Ancestor god ordines that her descendants should forever govern the land. It is for these reasons that the country has ever been governed by Sovereigns from the very beginning. Ever since the Imperial Ancestor first ascended the Throne, the whole land has been under Imperial rule, admitting of no challenge. ${ }^{6}$

No one has ever challenged the divine character of the Japanese Emperor, until the U.S. troops came to Japan in the summer of 1945.

This distinguishing trait of the Emperor is also the origin of the religious power, which is still connected nowadays to his figure. Due to his divine ascendance, he is considered a sort of bridge between the mortals' world and the gods' world and therefore, he is the highest Shinto ${ }^{7}$ priest. Being a member of the Shintō clergy has allowed the Emperor to perform duties and functions traditionally related to the religious and ceremonial sphere, rather than to the political one.

This claim has serious implications when coming to the political role of the Emperor, which has been traditionally quite unimportant. Indeed, Japanese Emperors have never ruled the country directly but in just two cases, which therefore represent an exception.

The direct imperial rule, called shinsei (新政), has taken place twice in Japanese history: the first period is between seventh and tenth century, thus covering the first half of the Heian Era (794-1185); while the second corresponds to the so-called Kenmu Restoration, between 1333 and 1336 . With respect to the first period, it is convenient to outline that in the second half of the Heian Era, the Emperor started to be flanked by councillors, gaining more and more importance and belonging to the all-powerful Fujiwara clan. The end of the Heian Era, in 1185, corresponded to the establishment of a military government, so-

(lacked by Chamberlain's), is by Donald L. Philippi (1 ${ }^{\text {st }}$ edition published in 1968 by the University of Tōkyō Press); this translation has not been re-published recently.

4 The most remarkable English translation is by William G. Aston in 1896, still available by different publishing houses.

5 This day was created a national holiday in 1966, as a day to reflect on the establishment of the nation and to nurture a love for the country. However, from 1872 until 1948, this very same day was the Empire Day (紀元節), a national holiday expressly commemorating Emperor Jinmu ascending the Throne. The shift in the denomination of the national holiday is not a matter of "small potatoes", since it reflects the radical transformation that affected the imperial institution in the aftermath of the war. See infra, par. 4.

${ }^{6}$ Fuji Shin'ichi, The Essential of Japanese Constitutional Law, Yuhikaku, Tōkyō, 1940, p. 412.

7 Shintō or Shintoism (神道) is the autochthonous religion and is centred on ritual practices to be carried out diligently in order to establish a connection with Japan's ancient past and ancestors. 
called Bakufu (or Shogunate) that led to the progressive overshadowing of the Emperor and of his capital, Kyōto. In this context took place the Kenmu Restoration, when Emperor Go-Daigo tried to restore the civil, rectius imperial, government over the military one of the Bakufu. The moment was well chosen by Go-Daigo since in 1333 we had the transition from the ruling of the Minamoto family (Kamakura Era 1185-1333) to the Ashikaga family (Muromachi Era 13361573). ${ }^{8}$

Therefore, starting from the Kamakura Period, the country was characterised by a two-headed power, the imperial one - dealing mainly with the religious sphere - in Kyōto and the shogunate one - dealing with the political sphere - in present-day Tōkyō.

From both a philosophical and political perspective, the Throne started to be considered as something distinctive of the Japanese identity and the Emperor as a ruler completely unrelated to any other king/emperor quite recently in time, starting from the late sixteenth century with the philosophical school of the Kokugaku (national or native study-国学). The Kokugaku stressed the purity of the Japanese national character - the so-called true heart of Japan - and for it to emerge all the foreign (at that time Chinese) influences are to be repealed. ${ }^{9}$ The following step was represented by the theory of Takenouchi Shikibu on absolute loyalty to the Emperor of Japan (Theory of revere the Emperor-sonno ron-尊皇論), that implied that less loyalty should be given to the ruling Tokugawa Shogunate. ${ }^{10}$

Similar ideas were expressed by scholars of the Mitogaku (水戸学), a school that developed in the the han (domain-藩) of Mito. ${ }^{11}$ In 1825, the Mito scholar Aizawa Seishisai in his work Shinron (New Theory-新論) wrote "Our Emperors, descendants of the Sun Goddess, Amaterasu, have acceded to the Imperial Throne in each and every generation, a unique fact that will never change. Our Divine Realm rightly constitutes the head and the shoulders of the world and controls all nations." ${ }^{12}$ Furthermore, "Ever since heaven separated from the earth

8 The struggle between Emperor Go-Daigo (1288-1339) and his successor and the Ashikaga family went on until 1392. This period, called Nanboku-chō Period (南北朝時代-South and North Courts Period) was characterised by the presence of two different courts and two different emperors, one in the North (in Kyōto), sponsored by the Ashikaga, and the other in the South (Yoshino, near Kyōto). In 1392 the Southern line gave up to the Northern line, from which descends the actual Emperor. However, since Go-Daigo took with him to Yoshino the three regalia - symbolizing the imperial legitimacy - the legitimacy of the Northern imperial line has been contested. The Japanese government himself claimed, in 1911, that the legitimate line was the Southern one. On the regalia, see infra, at footnote 65.

9 Michael Wachutka, Kokugaku in Meiji-period Japan: The Modern Transformation of 'National Learning' and the Formation of Scholarly Societies, Global Oriental, Leiden-Boston, 2013.

10 1600-1867. However, the first Tokugawa Shōgun, Tokugawa Ieyasu, officially become shogun in 1603. 1600 is the year of the Battle of Sekigahara, where the victory secured the Tokugawa rule.

11 The Mito domain is the present-day Ibaraki prefecture. The domain was ruled by a collateral branch of the Tokugawa clan. Along with the Tokugawa branches in Kii and Owari, the Mito branch represented one of the three Tokugawa houses known as the gosanke (御三家). These three branches descended from three sons of Tokugawa Ieyasu and they were owed to provide a Shogun in case of need.

12 In Kenneth J. Ruoff, The People's Emperor: Democracy and the Japanese Monarchy, 19451995, Harvard University Press, Cambridge-London, 2001, p. 18. 
and there were men, the Imperial descendants have ruled over the Four Seas (the Realm) in unbroken succession and without change in the one dynasty." 13

To conclude, what emerges from this brief overview on the key features of the imperial institution is mainly a divine Emperor, being at the centre of the religious and ceremonial sphere, but not a political ruler. Indeed, the real centre of political power has always be either the Fujiwara clan counselling the Heian Emperor or the Shoguns. ${ }^{14}$ Nevertheless, the Shogunate never challenged the role of the Emperor, quite the opposite. The Emperor remained the source of the Shogun's power, who ruled the country in his name. ${ }^{15}$ It is only starting from the early nineteenth century that a great emphasis was placed on the Emperor being the very heart of Japan.

That was the situation when commodore Matthew Perry of the U.S. Navy knocked at the doors of Japan, triggering a chain of events that led the country to a series of deep transformations.

\section{THE MEIJI ERA: A CONSTITUTIONAL FRAMEWORK FOR THE EMPEROR}

In 1853, when commodore Perry's kuro fune (black ships-黒船) entered the Uraga Bay in present-day Tōkyō (then Edo), demanding the opening of the ports to foreign trade, Japan was a peaceful feudal country, ${ }^{16}$ ruled by a Shōgun and a symbolic Emperor, with almost no contact with foreign powers. ${ }^{17}$ The country's legal system was still of a feudal nature, where the relationship between the ruler and the feudal lords (daimyo-大名) were of a private nature. ${ }^{18}$ Moreover, the total immobility between social classes and the absence of necessity to confront with other countries did not create the need for any legal reform. ${ }^{19}$

13 In Fuji Shin'ichi, The Essential of Japanese Constitutional Law, op. cit., p. 401.

14 The first shogunate family has been the one of the Miyamoto, starting in 1185; then, the Ashikaga (1337-1573) and the Tokugawa family (1600-1867) followed.

15 From the government of the Emperor to the government in the name of the Emperor, see William H. McCullough, "The Heian Court: 794-1070", in Donald H. Shively and William H. McCullough (eds.), The Cambridge History of Japan, Heian Japan, vol. 2, Cambridge University Press, Cambridge, 1999, pp. 41-42. The Cambridge History of Japan remains the most complete work on the history of the country.

16 There had been 253 years of peace, the so-called pax Tokugawa. The only exceptions have been the two Ōsaka campaigns in winter 1614 and spring 1615 against the Ōsaka castle and the remaining forces of the Toyotomi clan led by Toyotomi Hideyori. The Toyotomi clan was defeated at the battle of Sekigahara in 1600 by Tokugawa Ieyasu, the first Tokugawa Shögun.

17 The Netherlands were the exception to the general rule of the sakoku (鎖国), meaning the total closure of the country. Since the seventeenth century, the Dutch were allowed to trade with Japan but they could disembark and settle only in the small island of Dejima, in the bay of Nagasaki, in the Western island of Kyūshū.

18 The most remarkable work on Tokugawa Japan legal system is by John H. Wigmore (ed.), Law and Justice in Tokugawa Japan, Materials for the History of Japanese Law and Justice under the Tokugawa Shogunate, 1603-1867, Part I, Kokusai Bunka Shinkokai, Tōkyō, 1969. See also Dan Fenno Henderson, Conciliation and Japanese Law: Tokugawa and Modern, University of Washington Press, Seattle, 2 vol., 1965.

19 Herman Omms, Tokugawa Village Practice. Class, Status, Power, Law, University of Washington Press, Seattle, 1996. 
The cultural shock following the confronting with Western culture and the feeling of inadequacy that derived made the regime enter into a crisis. ${ }^{20}$ After a decade of civil war, where factions pro Emperor and against foreigners from the one hand ${ }^{21}$ and pro Shögun from the other fought each other, ${ }^{22}$ the awareness of the inadequacy of the country emerged abruptly, together with the strong determination to reach the Western model as the only possible way to fight properly the Western powers. The aim was clearly to seek a renegotiation of the unequal treaties that the country was forced to sign starting from the end of the 1850s.

During the Bakumatsu, samurai from the Western han of Satsuma e Chōshū, ${ }^{23}$ called shishi (志士), ${ }^{24}$ fought for the restoration of the political power in the hands of the Emperor (ōsei fukko-王政復古). According to their political motto "There cannot be two rulers in a land, or two heads in a house, and it is most reasonable to return administration and justice to one ruler." ${ }^{25}$

The crisis of the Shogunate led to the resignation in 1867 of the last Shogun, Tokugawa Yoshinobu, and to the restoration of the imperial rule: the Meiji Restoration of 1868. The use of words is always interesting because it conveys very specific meanings and may even manipulate the reality of facts. The use of the word restoration, from a strictly historical standpoint, is improper, since to restore something means to recreate a prior situation and the direct rule of the Emperor was something very remote in time, as previously outlined. The use of restoration was a great fiction from the part of the shishi that fought in the name of the Emperor and that became his most important counsellors (now called Oligarchs). The reason was that they needed to put the Emperor at the centre of the new system in order to justify the modernisation that was not always popular: ${ }^{26}$ the modernisation was carried out in the name of the Emperor. ${ }^{27}$

20 This period is called Bakumatsu, the end of the Bakufu (幕末) and covers the years from 1854 until 1867, when the last Shōgun, Tokugawa Yoshinobu (born Hitotsubashi Keiki and belonging to the Mito branch), relinquished the power, giving it back to the Emperor and leading to the socalled Meiji Restoration (Meiji Ishin-明治維新) in 1868. Therefore, 1868 is the turning point in Japanese history, as 1600 has been before and 1945 will be afterwards (1600 was the year of the battle of Sekigahara, which lead to the establishment of the Shogunate of the Tokugawa family after a period of political unrest, the Sengoku Jidai or period of warring states-戦国時代). The Meiji Era (era of the enlightened government-明治) lasted until 1912, year of death of the Meiji Emperor.

${ }^{21}$ This is the Sonnō Jōi (revere the Emperor and expel the barbarians-尊皇攘夷) movement that originated from the Mitogaku.

22 The attitude of this faction toward foreigners was ambivalent. The Shoggun knew that he was actually unable to expel them, since he lacked sufficient military strength. However, he knew that the presence of foreigners on Japanese soil was highly unpopular.

${ }^{23}$ Ruled by the Shimazu and Mori clans respectively. The feudal lords (daimyō-大名) ruling these domains were called tozama (外様), meaning literally the outside lords. This word was used to qualify all the feudal lords not being traditional Tokugawa vassals, whose great majority had their domains in the West and submitted to the Tokugawa after the Battle of Sekigahara (however, some tozama fought alongside the Tokugawa at Sekigahara).

24 The translation means men of high purpose.

25 In Marius B. Jansen, Sakamoto Ryōma, Princeton University Press, Princeton, 1961, p. 300.

${ }^{26}$ The mandatory cut of their top-knot (haircut edict-sanpatsudattōrei-散髪脱刀令) in 1871 and the prohibition for samurai to carry any weapon, mainly swords (sword abolishment edict-haitōrei- 
Immediately in the aftermath of the Restoration, the Oligarchs drafted a sort of road map aimed at shaping a new country based on Western knowledge. In order to do so, the sole possible solution to the newly created Meiji Government seemed to study Western powers social, legal and economic organisation and then to adapt their best practices to Japan. The studying phase was the key one, since from its results depended the whole future of the country. It was structured into two different moments: one consisted into inviting the most remarkable foreign scholars in a given area to $\operatorname{Japan}^{28}$ and the other into sending abroad prominent political figures and promising young people as study missions. ${ }^{29}$

Within the first category belonged the invitation of legal scholars such as Hermann Roesler - who would have drafted, together with the Prime Minister Itō Hirobumi, the 1889 Constitution -, Gustave Boissonade - the drafter of the Civil Code - and Alessandro Paternostro. While within the second, we can mention several missions, the most famous one being the Iwakura Mission, which, for two years (1871-1873), travelled across the U.S. and Europe, meeting heads of State and government, politicians and legal scholars. ${ }^{30}$

The Iwakura Mission was fundamental in the preliminary phase, when Japan had to choose which form of government suited the country best. Examining on the filed the functioning of the U.S. presidential executive, of the Westminster model, of the French Third Republic and of the continental Empires, the Japanese envoys could assess the concrete viability of the transplant of these forms of government within the Japanese context. Moreover, the aim of the mission was also to examine closely the legal system as a whole, in order to adapt the best solutions to Japan. ${ }^{31}$

廃刀令) in 1876 were highly unpopular. Besides, the abolition of the han system in 1871 had created a high number of unemployed samurai (so-called ronin-ろにん). The general malcontent of a consistent part of the samurai that had fought for the imperial restoration and that now felt let down by the new government triggered some rebellions, the most relevant one being the Satsuma rebellion in 1877, led by Saigo Takamori, the samurai leader of Satsuma during the Bakumatsu. This event is dramatized in the movie The Last Samurai (2003), starring Tom Cruise.

27 Carl F. Goodman, The Rule of Law in Japan, Kluwer Law International, The Hague, 2003, pp. 19-20. See Sterling and Peggy Seagrave, The Yamato Dynasty, Broadway Books, New York, 1999, p. 37. The same opinion is shared by the historians; see ex multis Edwin O. Reischauer, Storia del Giappone, Bompiani, Milano, 1998 (original edition 1989), p. 93.

28 See Mario Losano, Tre consiglieri giuridici europei e la nascita del Giappone moderno, il Mulino, Bologna, 1973; Il consigliere giuridico Hermann Roesler: problemi attuali della ricerca sulla sua attività, in Atti del sesto convegno di studi giapponesi, Aistugia, Firenze, 1983, pp. 151-186; Hermann Roesler, Berichte aus Japan (1879-1880), Unicopoli, Mailand, 1984; "La ricezione dei modelli giuridici europei nella realtà giapponese: Hermann Roesler (1834-1894)", Sociologia del diritto, 3/1984, pp. 29-44; "La modernizzazione giuridica del Giappone", in Enrica Collotti Pischel (ed.), Capire il Giappone, Franco Angeli, Milano, 1999, pp. 140-148; Tōkyō 1889: il corso di filosofia del diritto del consigliere giuridico Alessandro Paternostro", Rivista internazionale di filosofia del diritto, $\mathrm{n}^{\circ} 3,2006$, pp. 341-372.

29 The Shogunate too sent missions during the 1860s. See Fukase Tadakazu and Higuchi Yoichi, Le constitutionalisme et ses problèmes au Japon: une approche comparative, Presses Universitaires de France, Paris, 1984, p. 31.

30 On the Iwakura Mission, see Kume Kunitake, The Iwakura Embassy: 1871-1873, The Japan Documents, Chiba, 5 vol., 2002.

31 Giorgio Borsa, La nascita del mondo moderno in Asia Orientale, Rizzoli Editore, Milano, 1977, p. 441 . 
What clearly emerged from the two-year mission was the absolute need for Japan to adopt a written constitution and a series of codes, following the FrenchGerman model. ${ }^{32}$

For what concerns the imperial institution, what is relevant is the first point, the one related to the constitutional model. The analysis of both the U.S. and the French systems was considered by the Oligarchs fundamental, giving the importance of the tradition they enshrined. However, they were both discarded, since their being republics was enough to disqualify them as possible models.

Therefore, the favours went to the Westminster model and to the Prussian model, being both monarchical systems. From a closer look, it was immediately clear the difficulties lying in the transplant of a system so peculiar and so rooted in a particular tradition like the Westminster one. The Japanese society, with her traditions and background, could not have breaded such a transplant. Moreover, the British monarch was not comparable to the divine Japanese Emperor and the Oligarchs wanted to assign a more relevant role to the Emperor in the constitutional design. ${ }^{33}$

Therefore, the selected model was the Prussian model and the 1850 Constitution. Similarities were identified between the two countries and the strong role assigned by the Prussian Constitution to the King as source of the sovereign power suited the Japanese imperial figure.

Nevertheless, one of the most relevant issues discussed in the constitutional debate between 1869 and the enactment of the Meiji Constitution in 1889 was the role and powers of the Emperor in the new constitutional design. All the most prominent Oligarchs examined the issue and proposed their own solution either in a constitutional draft or in a more simple memorandum. All these drafts and memorandos, when coming to the imperial institution, represented an attempt to combine her traditional features, the "heart of Japan", with the pillars of Western constitutionalism.

\subsection{Kido Koin's constitutional draft}

The first constitutional draft, ${ }^{34}$ the one of Kido Koin, ${ }^{35}$ was remarkable for its liberal stance and the commitment toward a constitutional monarchy. Indeed the chapter devolved to the Emperor was the fourth, whereas the one enshrining the bill of rights was the second. For this reason was not considered as a viable

32 Particularly in the Civil Code (minpō-民法), the influence of the French jurist Boisonnade was prominent. Boissonade was invited in Japan in 1873 and remained there until 1895 . See Ōkubo Yasuo, “Gustave Boissonade: A Transplanter of Modern Western Law", Waseda Proceedings of Comparative Law, vol. 6, 2003, pp. 33-36 and Mario Losano, Tre consiglieri giuridici europei e la nascita del Giappone moderno, op. cit.

${ }^{33}$ However, some younger Oligarchs pushed for the adoption of the Westminster model (namely Inoue Kowashi).

${ }^{34}$ In George M. Beckmann, The Making of the Meiji Constitution, Greenwood Press, Westport, 1975, pp. 100-110.

35 1833-1877, known also as Kido Takayoshi and before the Restoration as Katsura Kogoro. The son a physician from Chōshū, he was one of the most relevant political leaders of the late Tokugawa and first Meiji Era. He took part to the Iwakura Mission. 
option by the other Oligarchs, whose majority favoured a more prominent role for the Emperor, at least formally.

In the shaping of the imperial role, Kido underlined the importance of the constitutional restraints towards the imperial power, since the risk of transformation into despotism had to be avoided. Therefore, according to Kido, the main goal of the constitution should have been to strike a balance between the imperial power and the respect of the individual sphere of the subjects.

Nevertheless, the Emperor was the source of the sovereign power, was sacred and inviolable. Moreover, the traditional imperial mythology was strongly affirmed, since the imperial succession has to be limited just to the line of Emperor Jinmu, thus reaffirming the divine and unbroken character of the Japanese monarchy, in spite of no clear mention of neither the divine nor the unbroken character. Moreover, a number of detailed provisions on regency and succession-related issues ${ }^{36}$ followed, all matters that the Meiji Constitution will almost entirely relinquish to the Imperial Household Law.

It is particularly interesting how Kido handled the responsibility issue. Article 38 affirms that the Emperor has the power to appoint and dismiss ministers, while Article 36 that his ministers shall always observe their responsibility to him. However, here Kido opens a parenthesis to explain the meaning of responsibility; Parliament may bring a complaint against a minister and that whenever such a minister is not able to explain his conduct, he will be dismissed from office.

Kido assigned to the Emperor broad political powers, more than he ever enjoyed. However, when focusing more on the effective exercise of such powers, that was up to his ministers. Thiers's lesson - Le roi n'administre pas, ne gouverne pas, il règne - had been learnt.

\subsection{The Genrōin draft}

In 1876 the office devoted to the study of a Constitution, chaired by the imperial Prince Arisugawa (who was also the chair of the Council of Elders, the Genrōin) was established. The tradition tells that the Meiji Emperor, when appointing Prince Arisugawa, gave him a copy of the Parliamentary Government in England by Alpheus Todd. This anecdote is emblematic of the commitment of both the Emperor and the Oligarchs to draft the best constitution possible for Japan. However, the Meiji Emperor also stressed that it was fundamental that the constitutional government was to be introduced to Japan gradually.

The Genrōin itself, from 1876 to 1878 , drafted four different constitutional proposals, submitting to the government just the last one, the 1878 version. ${ }^{37}$

\footnotetext{
${ }^{36}$ It is convenient to mention that, in case of no direct heir, i.e. a male heir, Kido provides for Ministers or Members of Parliament in council to elect the new Emperor from among the four Imperial Families (Article 46). At the time Kido wrote, the Imperial Family included a wide number of collateral branches and this excluded the possibility of a serious succession crisis. Nowadays, the new Imperial Household Law has reduced the Imperial Family to the descendants of Emperor Taishō (1879-1912-1926, the grandfather of the present Emperor). For this reason, in order to solve the problem of the scarceness of male members within the Imperial Family, one of the solutions proposed is to enlarge the Imperial Family.
}

37 In George M. Beckmann, The Making of the Meiji Constitution, op. cit., pp. 120-125. 
This draft showed the same concerns of Kido's with respect to the importance of establishing a system of check on imperial powers. In particular, the draft tried to transplant some sort of British parliamentary, providing for a legislative power shared between the Emperor and the Diet, with a concrete possibility for the latter to prevail. For this reason mainly, the Oligarchs rejected the draft since they did not considered suitable the prominence of the Diet. The reason was, as Iwakura affirmed, that in that draft " there are parts which do not conform with the National polity." 38

When coming to the Emperor, the Genroin draft devoted to him the first chapter, thus marking a significant difference with respect to draft by Kido. Nevertheless, Kido's chapter was much more detailed. However, the conciseness of the chapter did not prevent the Genroin to mark the core points of the Japanese tennōsei (imperial system-天皇制). Indeed, Article 1 stated that «The Japanese Empire shall be governed by an imperial line unbroken for ages." Moreover, as for Kido, he was sacred and inviolable (Article 2). However, no explicit reference was made to the sovereign power; rather, Article 3 affirms that the Emperor has a general "power of administration." On this point, some comments and notes of the members of the Genroin may be helpful in order to better clarify: it seems that they considered the sovereign power to be shared by the Emperor and the Diet. Therefore, no in-depth analysis is devolved to the imperial powers, besides the ones typical of a head of State.

\subsection{The Oligarchs' opinions on constitutional government}

Besides these first drafts, it is convenient to mention a series of equally important opinions on constitutional government, 39 drafted by the most prominent Oligarchs: Ōkubo Toshimichi (1873), ${ }^{40}$ Yamagata Aritomo (1979), ${ }^{41}$ Itō Hirobumi (1880), ${ }^{42}$ Ōkuma Shigenobu $(1881)^{43}$ and Iwakura Tomomi (1881). ${ }^{44}$ All

38 In George Akita, The Foundations of Constitutional Government in Modern Japan 1868-1910, Harvard University Press, Cambridge, 1967, p. 11.

39 All the texts of the opinions are in the appendices to George M. Beckmann, The Making of the Meiji Constitution, op. cit.

40 At pp. 111-119. Ōkubo (1830-1878) was a low-ranked samurai from Satsuma. He took part to the Iwakura Mission and was one of the founder of modern Japan. He was assassinated in 1878.

41 At pp. 126-130. Yamagata (1838-1922) was a low-ranked samurai from Chōshū. He later become the father of the modern Japanese army and twice prime minister (1889-1891 and 18981900). After the assassination of Itō in 1909, he became the power behind the government.

42 At pp. 131-135. Itō (1841-1909) was a low-ranked samurai from Chōshū. Between 1863 and 1864, together with Kido Takayoshi, he studied at University College London and this convinced him Japan needed to adopt Western ways. He took part to the Iwakura Mission. He was the main drafter of the Meiji Constitution and was prime minister four times (1885-1888; 1992-1996; 1898 and 1900-1901). He was assassinated in 1909.

43 At pp. 136-142. Ōkuma (1838-1922) before the Restoration entered into contact with Dutch missionaries who taught him English and provided him with a copy of the American Declaration of Independence. This marked his commitment toward a constitutional government. He was twice prime minister (1898 and 1914-1916) and founded one of the most renowned universities of Japan, Waseda, in 1882 . 
these opinions start upholding the unavoidability of both the Restoration and the commitment toward the modernisation of the country. Then they move on presenting considerations related to the constitutional government to be established, making comparative references to the Western systems, mainly the English one.

According to Ōkubo, a constitutional monarchy, granting the harmonic cooperation between the Emperor and the people was the sole possible government for Japan, since it was the most respectful of the Japanese tradition. Indeed, his opinion begins by going strict to the point: Japan cannot yet adopt democracy and cannot yet discard monarchy. Monarchy is rooted in the very founding of the Japanese nation. Whereas democracy is more suited to new countries, young and full of immigrants, such as the U.S. or South American countries. In other cases, such as in the French one, democracy has been much crueler than the absolute monarchy. Therefore, a system of government is established according to conditions, customs and feelings of the people of a given country. Japan never had a government that did not include the people nor was maintained without the monarchy. Constitutional monarchy is the juncture: is the joint government of the ruler and the people; therefore, she is limited. The aim is to determine the powers of both in an equitable fashion and the constitution is the supreme law of the land. For this reason, limited monarchy has to be preferred over monarchical absolutism. Therefore, he upholds the separation of powers as a founding principle of the new government. Nevertheless, he recognises the difficulties to apply the principle to the Japanese traditional system. When coming to outline the role of the Emperor in the new system, that should be pivotal. The Emperor had to rule directly the country, meaning that the constitution had to enshrine the substantive power of the Emperor. The Emperor has the supreme power in the operation of the nation administration. Therefore, he rejects all the proposals in favour of a formal ruling of the Emperor and of a substantive ruling of his ministers. Japan had already known the formal ruling of the Emperor during the centuries of the Shogunate and now she had to move forward. Ōkubo's Emperor was thus entitled a wide range of political powers that put under strain the separation of powers. Emblematic is his statement according to which the Emperor "is not restricted by law."

Yamagata's memorandum stresses the importance of the traditional tennōsei, affirming that Japan would have been "forever governed by an Emperor of an unbroken family lineage." He advocates the necessity to uphold the principle of the separation of powers as the sole possibility to preserve the prestige of the Throne and the respect for the Emperor. His main point is the establishment of an assembly with extensive powers; nevertheless, he warns that this needs to be done gradually. However, this is an inevitable measure toward the development of the nation.

Itō, after a brief account on the critical situation of the country, immediately outlines the importance of establishing a Parliament. This would represent the first step toward a limited monarchy. However, although this is very desirable, the kokutai (literally the body of the country, more frequently traduced as

44 At pp. 143-148. Iwakura (1825-1883) was the son of a low-ranking courtier and progressively gained the trust of the young Emperor Meiji. He was the leader of the eponymous mission. 
national polity-国体) has not be altered. Moreover, Itō stress the importance of the Emperor's commitment toward the establishment of a constitutional government as the sole possible chance of a successful transition from the old to the new system. However, nothing more is said on the Emperor's role and powers.

Ōkuma's opinion is undoubtedly the most liberal and less centred on the Emperor. His second point (after the establishment of a Parliament) provides for the Emperor appointing officials on the basis of the support of the people, meaning that he should consider the confidence of the people. This is the distinguishing element from the absolutist form of government. Moreover, Ōkuma underlines that when an official is appointed in this manner, the Emperor himself will be more esteemed. He goes on clarifying that the will of the people is represented by more than a half of the members of Parliament and since they are elected by the people, their will is the will of the people. The best person to express the will of the people is the leader of the majority party. Therefore, since he controls the legislature, he has to be the Emperor choice for the prominent position within the government. In doing so, the Emperor can control both the legislature and the administration. For this reason, it is vital that a shift of party power in Parliament is reflected by a change in high officials. This is the essence of the constitutional government. The next step in Ōkuma's reasoning is the relationship of confidence as the key rule governing the relationship between Parliament and cabinet. The Emperor, because of the English experience, can dismiss from office the government that refuses to resign. When coming to the power of dissolution, Ōkuma mainly assigns it to the cabinet, although the approval of the Emperor is required. Point four is represented by the establishment of a constitution. The constitution should be very brief, just an outline that clearly states where the power is vested and that enshrines the protection of the rights of the people. The implementation of a party government does not prevent abuses from the government, unless there are constitutional provisions granting popular rights.

The Iwakura opinion has to be mentioned since it advocates for the first time the Prussian choice as the sole possible model for Japan. Other continental monarchies, such as Great Britain, Belgium and Italy, had to be discarded, since they assigned too much a prominent role to the Parliament (in particular with respect to the tax raising power), thus compressing the one of the monarch. When comparing the role of the British king with the one of the Emperor, he outlined that they both have power in name only. ${ }^{45}$ On the contrary in Prussia the king does not only reigns but exercises the administrative power, thus he is not subject to the control of Parliament. Iwakura recognises that the establishment of a constitutional government is something new for Japan; therefore, the choice of the model will affect the future of the country for at least a hundred years. Moreover, since Japan has no experience at all, she needs to move gradually and carefully, because not all the choices can be taken back. This is the reason why Iwakura favours the Prussian option, despite he admits that there is a certain degree of absolutism in the Prussian Constitution. Iwakura identifies three main points that Japan should borrow from Prussia: the Emperor appoints and dismisses the ministers (therefore, no possibility for Parliament to pass a no confidence vote); no collective responsibility of the ministers (opposite

45 The reference here was to Japan until the Restoration. 
to the French experience) and finally the tax raising power has to remain in the hands of the government. This final point is considered the core one, since even though the constitution provides for a cabinet not depending on Parliament but the latter is entrusted the tax raising power, the power of the Emperor will be severely diminished.

\subsection{Itō meets the Germans}

Despite the high number of constitutional drafts and opinions, the constitution was still far away to come. There was a general agreement between the Oligarchs on some key issues; however, there was no common position on the model to adopt. The British and the Prussian option seemed the only ones remained viable. Therefore, in order to try to speed up the process, the Emperor sent again Prince Itō to Europe in 1882 in order to perform a closer examination of these two monarchies. Since he had already an experience of the British one, he focused mainly on studying the German-speaking leading scholars. It was following these encounters in Berlin and Vienna that he definitively embraced the Prussian choice proposed the previous year by Iwakura. Itō already had started to be keener on this option since 1878, when the German scholar Hermann Roesler arrived in Japan.

In Berlin, Itō met Lorenz von Gneist and this encounter sealed the ultimate choice in favour of the Prussian model (already advocated by Iwakura). According to von Gneist, a constitution had to be rooted in a country's history and tradition and thus, when modernise the system, it was a core point not to neglect them. Therefore, according to him, the new Japanese constitution should strengthen the imperial powers, in particular when coming to foreign policy, armed forces and legislative power.

Equally crucial for Itō, was the meeting in Vienna with Rudolf von Stein, who theorised a "bureaucratic constitutionalism", an authoritarian form where the concepts of state and Emperor overlapped and the ministerial responsibility worked towards the Emperor and not towards the Parliament.

When back to Japan, Itō was entrusted the chair of the drafting commission. The main counsellor was Roesler. Besides them, mainly Roesler's pupils, such as Inoue Kowashi, ${ }^{46}$ Itō Miyoji ${ }^{47}$ and Kaneko Kentarō composed the commission.

According to Roesler, the Emperor had to be qualified as the source of any power and had to be entrusted with very precise powers in both the executive and the legislative fields; moreover, the ministers had to be responsible towards him and not to the Diet.

\subsection{The Meiji Constitution}

The Meiji Constitution, granted to the subjects by the Emperor, was promulgated on the $11^{\text {th }}$ February 1889 and entered into force the following

\footnotetext{
46 Itō recognised the key role played by him in the drafting process: "Man muss wiessen, dass ich den kaiserlichen Auftrag ohne diesen Mann nicht hätte erfüllen könne", in Suzuki Yasuzo, "Hermann Roesler und die Japanische Verfassung”, Monumenta Nipponica, vol. 4, n 1, 1941 , p. 55.

47 The English translation of the Meiji Constitution is by Itō Miyoji.
} 
year. ${ }^{48}$ Almost two decades were needed to study, examine and draft a constitutional text that was suitable for Japan. The role played by German scholars, Roesler in particular, was crucial in shaping a constitutional system that conferred a prominent role to an Emperor who embodied the traditional characters of divine ascendance and inviolability. Despite the European framework, the constitutional design of the Emperor was so Japanese that some Japanese scholars qualified the Meiji Constitution as a document disclosed by the Sun goddess Amaterasu, which made it unique in the world. ${ }^{49}$ Therefore, neither a granted nor a voted constitution.....

The tennōsei shaped by the new constitution is a combination of both traditional and innovative (European) elements. The tradition is embodied in the Preamble and at Articles 1-3; the innovation at Article 4 (and the following, listing all the imperial powers, similar to the ones of in European monarch).

It is convenient to underline that the imperial institution has been a sort of battleground for two opposite legal cultures and traditions, which interpreted the sovereign, his role and his powers very differently. Indeed, Roesler advocated for an Emperor modelled after European constitutions, namely without any religious reference, whereas Itō stressed the importance of this religious connotation, since it marked the continuity with the Japanese tradition. Therefore, Roesler in his personal draft shaped a constitutional and secular monarch, thus qualifying the Empire of Japan as a constitutional monarchy. ${ }^{50}$ Roesler was not disregarding the traditional kokutai, rather, he believed that it was not necessary to expressly enshrine it in a constitutional provision; what mattered was the preservation of the imperial tradition. According to Roesler "a constitution is a fundamental law by which the subjects are admitted to the enjoyment of certain rights in respect of the government", ${ }^{51}$ while for Itō "the first principle of our constitution is the respect of the sovereign rights of the Emperor."

Despite the huge influence that German legal scholars and culture exercised in the shaping of the new Japanese legal system, it was not so strong as to alter the core of the imperial institution, namely the reference to the bansei ikkei (a single-family lineage for eternity-万世一系), "a line of Emperors unbroken for ages eternal."

Therefore, Article 1 embodies the Japanese kokutai, the foundation of the State. For this reason, it was considered to be beyond any possible future amendment. Itō in his Commentaries considered advisable to expressly affirm that no new opinion was enshrined in the Constitution; quite the opposite, the

48 Lawrence W. Beer and John M. Maki, From Imperial Myth to Democracy: Japan's Two Constitutions, 1889-2002, University Press of Colorado, Boulder, 2002.

${ }^{49}$ Fuji Shin'ichi, The Essential of Japanese Constitutional Law, op. cit., p. 331. It was also the first Western-style constitution to be adopted by an Asian country.

50 Johannes Siemes, Hermann Roesler and the Making of the Meiji Constitution: with his Commentaries on the Meiji Constitution, Sophia University Press, Tōkyō, 1966, p. 18. The same text is available in Johannes Siemes, "Hermann Roesler's Commentaries on the Meiji Constitution, Monumenta Nipponica, vol. 17, $\mathrm{n}^{\circ}$ 1-4, 1960, pp. 1-66.

51 Johannes Siemes, Hermann Roesler and the Making of the Meiji Constitution: with his Commentaries on the Meiji Constitution, op. cit., p. 40. 
"original national polity is by no means changed by it, but is more strongly confirmed than ever."52

Another important trait of the Japanese Emperor derives form Article 3: is sacred and inviolable, unlike the European monarchs. However, they share the common trait of the irresponsibility (inviolability), but the latter are never qualified as sacred. Moreover, affirms Itō, the law has no power to hold the Emperor accountable. ${ }^{53}$

Furthermore, Article 4 affirms that all the sovereign powers are combined in the Emperor, who excises them, according to the provisions of the Constitution. Both Roesler and Ito further stressed the importance of the unity of the sovereign power, with the limits provided for by the Constitution. The exercise of the sovereign power should never result into despotism. The limits represented by the Constitution had not to be interpreted, according to Roesler, as something inconsistent with the sovereign power, which has no limits; what was relevant was that the Constitution did not "unreasonably check and weaken it." 54 Moreover, since the Constitution was granted, it was the Emperor himself deciding to submit to such limits. However, not all the Japanese legal scholars shared this interpretation. According to Hozumi Yatsuka (1860-1912), one of the major conservative scholars, "the Constitution has no power to limit sovereignty."55 Itō uphold the separation of powers, as a cornerstone principle of the Constitution, pointing out, however, that it is necessary that they can all three traced back to the Emperor. 56

When trying to define what the Meiji Constitution was, a good definition is that she express the so-called Schein Konstitutionalismus, ${ }^{57}$ through which an authoritarian system centred on the Emperor was established. The Emperor was surrounded by a sacred and mystical aura, which had no counterpart in any Western constitution. Therefore, the system emerging from the Meiji Constitution was hybrid; to quote Roesler "the Japanese constitution has been modelled according to true constitutional principles which are recognized everywhere. But it cannot in its particulars be criticized according to the constitutional law or

52 Itō Hirobumi, Commentaries on the Constitution of the Empire of Japan, University Publications of America, Washington, 1979, p. 2.

53 Itō Hirobumi, Commentaries on the Constitution of the Empire of Japan, op. cit., p. 7.

54 Johannes Siemes, Hermann Roesler and the Making of the Meiji Constitution: with his Commentaries on the Meiji Constitution, op. cit., p. 48.

55 Cfr. Richard H. Minear, Japanese Tradition and Western Law: Emperor, State, and Law in the Thought of Hozumi Yatsuka, Harvard University Press, Cambridge, 1970, p. 97.

56 Itō Hirobumi, Commentaries on the Constitution of the Empire of Japan, op. cit., pp. 9-10.

57 Okudaira Yasuhiro, "Forty Years of the Constitution and Its Various Influences: Japanese, American, and European", in Percy R. Luney jr. and Takahashi Kazuyuki (eds.), Japanese Constitutional Law, University of Tōkyō Press, Tōkyō, 1993, p. 6. The same text is also available in Law and Contemporary Problems, vol. 53, $\mathrm{n}^{\circ}$ 1, The Constitution of Japan: the Fifth Decade [Part 1], 1990, pp. 17-49. See also Fukase Tadakazu and Higuchi Yoichi, Le constitutionalisme et ses problèmes au Japon: une approche comparative, op. cit., p. 16 ; Nakamura Kichisaburo, The Formation of Modern Japan: As viewed from Legal History, The Centre of East Asian Cultural Studies, Tōkyō, 1962, p. 9. Johannes Siemes disagrees on this definition, since strong limitations are provided on the imperial powers: Johannes Siemes, Hermann Roesler and the Making of the Meiji Constitution: with his Commentaries on the Meiji Constitution, op. cit., p. 24. 
practice of special other countries; in its own peculiar features it must be regarded as a pure Japanese law, adapted to the national character of the Japanese people.»58

\subsection{Interpreting the Meiji Constitution and the Tennōsei Fashizumu}

The ambiguity of the Meiji Constitution in define both her role (a limit to the sovereign power) and the one of the Emperor led in the following decades, mainly starting from the $1920 \mathrm{~s}$, to a sort of involution of the tennosei. 59 The gradual disappearance of the Oligarchs, who all favoured a limited monarchy. The mental illness of Emperor Taishō and the post-war economic crisis turned into a breeding ground for a rising nationalism and the military acquired importance, even in the ruling of the country.

The Meiji institutions, maybe due to that ambiguity, proved very adaptable both to an emerging liberal democracy during the Taishō Era-大正時代 (era of great righteousness, 1912-1926, the so-called Taishō democracy) and to a more authoritarian and militarist state in the Shōwa Era-昭和時代 (era of enlightened peace/harmony, 1926-1989). ${ }^{60}$ Due to the influence of the military, the form of State shifted from liberal to fascist.

The Japanese fascism was not centred on a charismatic party leader, conveying a new ideology, since it was not necessary. The country already had a natural leader in the person of the Emperor. The leader was the Emperor and the ideology was the traditional imperial system, the tennōsei. Indeed, the Japanese fascism is called tennōsei fashizumu. 61

Totalitarian systems are usually founded on three circles: the man, the system (repressive) and the ideology. ${ }^{62}$ Wirth respect to this model, Japan is quite peculiar. Considering the first circle, the man, the Japanese fascism was never centred on a man, not even the Emperor. Better, not on the Emperor as a man. What was revered was the imperial institution as the core foundation of the nation, regardless of the man who was actually the Emperor. The cult of the Emperor was nothing similar the cult of personality characterising the European totalitarian regimes. The second circle too reflected the Japanese peculiarities. Rather than on physical elimination, it was centred on ideological conversion, in

58 V. Johannes Siemes, Hermann Roesler's Commentaries on the Meiji Constitution, op. cit., p. 19.

59 Paolo Biscaretti's volume on the constitutional system of Japan in the Shōwa Era offers a very interesting look on the interpretation of the peculiarities of the Japanese constitutional system, at a cross-road between Western and traditional influences, by a foreign scholar, which was not specialised on Japan. See Paolo Biscaretti Di Ruffia, Il diritto costituzionale dell'Impero nipponico, Giuffrè, Milano, 1943 (in particular pp. 89-103).

60 The authoritarian and militarist period within the Shōwa Era lasted until the war defeat in 1945. For an overall review on what remained of right-wing nationalism in the aftermath of the war, see Ivan I. Morris, Nationalism and the Right Wing in Japan. A study of post-war trends, Oxford University Press, Oxford, 1960.

61 Maruyama Masao, Thought and Behaviour in Modern Japanese Politics, Oxford University Press, Oxford, 1963.

${ }^{62}$ Eric Seizelet, Monarchie et démocratie dans le Japon d'après-guerre, Maisonneuve\&Larose, Paris, 1990, pp. 50-51. 
order to have the dissident reintegrated in the social group. ${ }^{63}$ Coming to the third circle, the ideology too was lacking. Tennōsei and kokutai were more mystique rather than typical totalitarian ideologies, thus conveyed more religious than political concepts.

However, these differences did not prevent Japan from reaching the level of extremism characterising European totalitarian regimes.

Illustrative of the extremism reached by the imperial mystique are the words of the home secretary Hiranuma Kiichirō, in 1941: "Japan's National polity [kokutai] is unique in the world. ... Dynasties in foreign countries were created by men. Foreign kings, emperors and presidents are all created by men, but Japan has a Sacred Throne inherited from the Imperial Ancestors. Japanese Imperial Rule, therefore, is an extension of Heaven. Dynasties created by men may collapse, but the Heaven-created Throne is beyond men's power."64

The tennōsei fashizumu was built on two main pillars that both placed the Emperor at their centre: the education system and the Shintō religion.

Education was crucial in order to mould the minds of younger generations and to breed them in the cult of the Emperor. All school children had to recite the Imperial Rescript on Education, a ritual pledge to offer one's body and soul to the Emperor.

The Shintō religion supported the imperial mystique by providing for the religious framework, strengthening the divine nature of the Emperor. The Emperor, being a living god, was also the highest priest, the only one allowed to see the Three Sacred Treasures, representing the three primary virtues: valour (the sword), wisdom (the mirror), and benevolence (the jewel). ${ }^{65}$ Their possession legitimates the Emperor as such and as a divine being.

As previously outlined, the Schein Kontitutionalismus characterising the Meiji Constitution has given rise to different interpretations, in particular with respect to the imperial institution. The theories of the most conservative legal scholars of the late Meiji and early Taishō Era provided for the doctrinal support to the imperial ideology of the 1920s and 1930s, thus strengthening the conservative interpretation of the Meiji Constitution. The two most relevant supporters of this interpretation were Hozumi Yatsuka (1860-1912) 66 and his pupil Uesugi

63 The repressive system and the control on thoughts were highly developed, in particular after the enforcement of the Chian Iji Hō (peace preservation law-治安維持法) in 1925. On the system, see Richard H. Mitchell, Japan's Peace Preservation's Law of 1925: Its Origins and Significance, Monumenta Nipponica, vol. 28, $\mathrm{n}^{\circ}$ 3, 1973, pp. 317-345 and Censorship in Imperial Japan, Princeton University Press, Princeton, 1983.

64 In Kenneth J. Ruoff, The People's Emperor: Democracy and the Japanese Monarchy, 19451995, op. cit., p. 40.

65 Due to the legendary status of the Three Imperial Regalia (Sanshu no Jingi/Mikusa no Kandakara-三種の神器), their locations are not confirmed, but it is commonly thought that the sword (Kusanagi no Tachi-草那芸之太刀) is located at the Atsuta Jingu in Nagoya, the jewel (Yasakami no Matagama-八尺瓊勾玉) at the Three Palace Sanctuaries in Kyōkyo (the Imperial Palace in Tōkyō), and the mirror (Yata no Kagami-八题鏡) at the Ise Jingu (the Naiku shrine) in Mie Prefecture.

${ }^{66}$ Again on Hozumi, Richard H. Minear, Japanese Tradition and Western Law: Emperor, State, and Law in the Thought of Hozumi Yatsuka, op. cit. 
Shinkichi (1879-1929). According to their theory, the Emperor was an absolute ruler and his person coincided with the State; Hozumi stated that «天皇はすなわち 国家である。"(Tennōwa sunawachi kokka de aru). Moreover, sovereignty was the constituent element of the State and thus had to be boundless. Besides, the State was considered as a legal person hōjin (法人) having a legal will, while the natural will was represented by the Emperor. This interpretation clearly echoed Laband's theory on the natural will of the monarch and the legal will of the State. This marks the most significant difference with respect to the constitutional doctrine of the Oligarchs, according to which the Emperor was not the State (as affirmed by Itō in his Commentaries).

To quote Hozumi again: "He who is sovereign is sovereign according to his own innate strength, and the power he exercises is his own innate power. ... This is the special feature of the monarchical kokutain; 67 thus, the kokutai is characterized by the fact that "the legal will of the state is established from the natural will of a specific individual.»68 Since the Emperor is the subject of sovereignty, sovereignty is innate to him; therefore the Emperor is the State and not an organ of the State (as later Minobe will argue). Hozumi again: "the characteristic of the Japanese monarchical state is that the natural will of a definite individual completely constitutes the legal will of the state. The will of the Emperor is the will of the state. The monarchy and the state are identical; in other words, the Emperor is the state." 69 Again echoes of the theories on sovereignty von Schulze, Laband e von Rönne. Laband, in particular, argued that there was no other will above the one of the sovereign. ${ }^{70}$

The next step in Hozumi's theory was to deny the ministerial responsibility in place of the Emperor. In principle no one has the right to question the Emperor; and there is "no need for anyone to receive such questioning in place of the emperor." ${ }^{71}$

The constitution as a limit to imperial powers was a self-restraint of the Emperor. This interpretation seems to be close to Jellinek's, ${ }^{72}$ but, opposite to him, Hozumi believed that this self-restraint could have been revoked by the Emperor, as far as to take back the Constitution. Therefore, Hozumi came to distinguish to types of sovereignty: the one in her true form, supreme and boundless, granting constitutional documents; the other in her constitutional display, acting in compliance with the Constitution. The first sovereignty belongs to the Emperor, while the second is divided between the three branches of government.

67 Richard H. Minear, Japanese Tradition and Western Law: Emperor, State, and Law in the Thought of Hozumi Yatsuka, op. cit., p. 62.

68 Richard H. Minear, Japanese Tradition and Western Law: Emperor, State, and Law in the Thought of Hozumi Yatsuka, op. cit., p. 63.

${ }^{69}$ In Kenneth Colegrove, "The Japanese Emperor", The American Political Science Review, vol. 31, $\mathrm{n}^{\circ}$ 6, 1937, p. 649.

70 Cfr. Paul Laband, Das Staatsrecht des Deutschen Reiches, II, Mohr, Freiburg im B., 1981 (first published in 1876-1882), pp. 34-35.

${ }^{71}$ Richard H. Minear, Japanese Tradition and Western Law: Emperor, State, and Law in the Thought of Hozumi Yatsuka, op. cit., p. 107.

72 Georg Jellinek, Allgemeine Staatslehre, Häring, Berlin, 1900. 
In 1911, Uesugi theorized the theory called of tennō shukensetsu (主権説), whose distinguishing feature was the imperial absolutism, deriving straight from Hozumi.

Fuji Shin'ichi, in line with Hozumi and Uesugi's theories, founded the Japanese kokutai on four main elements: "the great spirit of the foundation; the unbroken line; the historical solidarity of the country's independence; and the nation's firm conviction of the imperishability of the State." ${ }^{73}$

This group of conservative theories emphasised the imperial role as source and centre of the State activity, even proposing an overlapping between him and the State. However, there was actually no real correspondence of these theories in the political life of the country, since everything was just in the name of the Emperor.

A significant opposition to Hozumi, Uesugi and Fuji came from another leading constitutional scholar, Minobe Tatsukichi (1873-1948), ${ }^{74}$ who claimed that the Emperor of the Meiji Constitution was a constitutional monarch. His main theory was the tennō kikansetsu (天皇機関説) or organic theory of 1912 . According to this theory, the Emperor was not the State, rather an organ of the State, as the Diet was or the government. Minobe interpreted the constitution as assigning to the Diet a central role, as the main organ of the State, just after the Emperor. Therefore, Japan was a constitutional monarchy and thus "Sovereignty is vested in the state and not in the Emperor; although it is possible that the Emperor exercises sovereignty under the constitution"; furthermore: "I believe that to regard the kokka tosuiken (国家統帥権), or sovereignty of the state, or the right of governing the state, as a personal right of the Emperor is contrary to the fundamental nature of the Japanese state (kokutai) and contrary to the spirit of Japanese constitution." 75 To further sustain his theory, Minobe pointed out that all matters related to the Imperial Family were not regulated by the Constitution but by the Imperial Household Law, thus separating de facto the Emperor from the State.

Minobe was harshly criticised and hardly hit by the censorship of the regime; he was forced out the House of Peers and of the University. In this occasion, the government felt the need to better specify the role of the Emperor within the system: "The Japanese doctrine of placing the imperial family at the center of the national structure is based upon the 3,000-year-old faith and conviction of the Japanese people that the prerogatives of the Emperor - that is, the State - are omnipotent and supreme." ${ }^{76}$

However, it is convenient to outline that Article 1 could have been used as a base for both Uesugi and Minobe's theories. Again, the ambiguity of the text was recognized by Minobe that wrote, in his 1926 Kenpō Satsuyō (Outline of Constitutional Law-憲法撮要): “Since its promulgation, our constitution has developed in a manner completely contrary to the expectations of its authors.

73 Fuji Shin'ichi, The Essential of Japanese Constitutional Law, op. cit., p. 396.

74 On Minobe, see Frank O. Miller, Minobe Tatsukichi: Interpreter of Constitutionalism in Japan, University of California Press, Berkeley-Los Angeles, 1965.

75 In Kenneth Colegrove, “The Japanese Emperor”, op. cit., p. 651.

76 In Time, 22-4-1935. 
Institutionally the system of cabinet responsible to the Diet has no place in the constitution, but it has been established as a customary practice. It is now recognized as a natural principle that when there is a loss of Diet confidence, especially in the House of Representatives, the cabinet must dissolve the lower house and appeal to public opinion, or it must offer a general resignation.»77

\section{FROM HEAVEN TO EARTH: A NEW CONSTITUTION FOR A NEW EMPEROR}

The degeneration of the tennōsei that had characterised the 1930s and 1940s had disastrous effects on the country, since it was the primary cause of the war tragedy and of the "atomic sunshine" of Hiroshima and Nagasaki. The occupation of the country by the Allied - U.S. troops mainly ${ }^{78}$ - that followed, had as major aim the dismantling of the tennōsei and the democratisation of the country. ${ }^{79}$ And of course the drafting of a new constitution. ${ }^{80}$

The democratisation, with everything associated to it, was point no. 10 of the Potsdam Declaration that Japan had signed together with the Instrument of Surrender on the $15^{\text {th }}$ August $1945 .{ }^{81}$ Democratise the country meant an overall reform, starting from the Emperor institution and the Meiji Constitution, and then continuing to education, religion and economy.

Another legal transplant was at the gate. However, this time, already from the start, it seemed unlikely for Japan to have the possibility to preserve her own traditional features or to have some room for negotiation. The Supreme Commander for Allied Powers (SCAP), General Douglas MacArthur had already planned to completely overthrow the tennōsei.

Various proposals for democratising Japan were drafted since the war started, in December 1941. Immediately become clear that the core point that any reform should have faced was the role of the Emperor and the necessity of completely restructure his constitutional role. ${ }^{82}$ The U.S. were well aware that, for

77 In Mitani Taichirō, “The Establishment of Party Cabinets, 1898-1932”, in Peter Duus (ed.), The Cambridge History of Japan, vol. 6, The Twentieth Century, Cambridge University Press, Cambridge, 1988 , p. 56.

78 The Allied were quite unsatisfied with the U.S. handling of the Japanese issue. Therefore, Soviet Union, U.K. and China submitted a proposal for the establishing of the Far Eastern Advisory Commission. The Commission was composed of representatives of those countries whose governments joined the agreement and her powers were to make policy recommendations to the U.S. government in enforcing the provisions of the instrument of surrender. MacArthur was not in favour of the Commission and speeded up the constitutional drafting process in order to conclude it before the Commission concretely started to operate.

79 Lawrence Beer and John.M. Maki, From Imperial Myth to Democracy: Japan's Two Constitutions, 1889-2002, op. cit.

80 One of the first studies on the new constitution, which was approved on the $3^{\text {rd }}$ of November 1946 and entered into force on the $3^{\text {rd }}$ of May 1947, is by Francesco Valoti, Il Sistema costituzionale giapponese, Sansoni, Firenze, 1946.

81 The signing of the Declaration has been considered by itself a proper revolution, the so-called August Revolution.

82 A full and detailed account of the U.S. approach to the inevitable restructuring of Japan is in Dale M. Hellegers, We, the Japanese People: World War II and the Origins of the Japanese Constitution, Washington, vol. 1, Stanford University Press, Stanford, 2002. 
any reform of the imperial institution to succeed, education and religion - the two pillars founding the imperial mystique - and the connected repressive system were to be democratised. Surely, the U.S. misunderstood the political role of the Emperor, mainly because the imperial fascism had emphasised the imperial figure and the Meiji Constitutional allowed it. Indeed, on the basis of a strict interpretation of the Meiji Constitution, the powers belonging to the Emperor were actually exercised by the Oligarchs first and then by the military.

However, until the end of the war, no definitive policy on that issue was formulated by the U.S.

Besides the reform issue, the Emperor had to face a far more dangerous challenge: his responsibility in the war. All the Allied but the U.S. ${ }^{83}$ held the Emperor responsible of the war crimes perpetrated in Far East Asia ${ }^{84}$ and wanted him put on trial at the Tōkyō Trials. ${ }^{85}$ General MacArthur did not favour this option mainly because he understood the key role that could have been played by the Emperor in democratising the country. 86 The SCAP planned to shield behind the Emperor in order to get support to his democratisation politics, whose last step was the democratisation of the imperial institution itself. Indeed, since 1943, the option of the termination of the imperial institution was put aside, since he could have be an asset of great utility for the changes the U.S. had in mind for the country.

In order to shield the Emperor from the hypothesis of a trial, the SCAP started to dismantle the imperial mystique by separating the Emperor from the Shintō. On the $12^{\text {th }}$ of December 1945, the SCAP issued the so-called Shintō directive Abolition of Government Sponsorship, Support, Preparation, Control, and Dissemination of State Shintō. The following step was having the Emperor broadcast a declaration. On in $1^{\text {st }}$ of January 1946, for the first time, the Japanese people heard the voice of the Emperor, telling them something astonishing, declaring himself a human being, thus relinquishing his divine ascendance and nature. It was the Declaration of Humanity (Ningen Sengen-人間宣 言). 87 The Emperor stated that the bond between himself and his people «do not

83 At a governmental level. Indeed in September 1945 a Democratic Senator form Georgia introduced a joint resolution in Congress affirming that the U.S. should try the Emperor as a war criminal.

84 The Japanese crimes are still an object of controversy and tension between Japan and some of her neighbours, mainly China (for the "rape" of Nanking of 1937) and south Korea (for issue of the "comfort women").

85 On the Tōkyō Trials, see Richard H. Minear, Victor's Justice: The Tōkyō War Crimes Trial, Princeton University Press, Princeton, 1971.

86 MacArthur was impressed when the Emperor visited him at the embassy on the $27^{\text {th }}$ September taking full responsibility of the war.

87 The Declaration marked a significant shift from the past also for the language used by the Emperor, less formal and dignified and thus more comprehensible to all the Japanese. Nevertheless, the true meaning of the Declaration has been long debated with respect to the Japanese text. The Japanese equivalent of the phrase officially translated into English as "the false conception that the Emperor is divine" has a very peculiar wording, since it uses the unusual word akitsumikami (現御神) instead of the more common arahitogami (living god-現人神). While akitsumikami is usually glossed as divinity in English, some Western scholars, such as Herbert P. Bix (in Hirohito and the making of modern Japan, Perennial, New York, 2001), have 
depend upon mere legends and myths. They are not predicated on the false conception that the emperor is divine and that the Japanese people are superior to other races and fated to rule the world." 88

In fostering the Emperor to take and to support these necessary steps toward the promotion of a new imperial institution, the SCAP laid the foundations for the constitutional revolution that enshrined this new imperial path.

The drafting procedure of the new constitutional document - which followed the amendment procedure provided for by the Meiji Constitution at Article $73^{89}-$ was highly tense and its legitimacy is still debated today. ${ }^{90}$ For two main reasons: first, it altered the sovereignty principle, which is considered beyond the possibility of an amendment procedure; second, the ones who concretely wrote the constitutional text were the members of the GHQ, since the government was reluctant at implementing the necessary reform (in particular of the tradition kokutai). ${ }^{91}$

The alteration of the sovereignty principle was considered by the U.S. unavoidable. Therefore, the issue of the constitutionality of a constitutional amendment altering the sovereignty principle, which the Meiji scholars have always considered to be unamendable, was completely discarded. It was the seal on the new Japan and of her newly acquired democracy. The Emperor could have remained the central pillar of the Japanese nation, but as a symbol not as a divine ruler. The democratization was meaningless without the affirmation of the principle of popular sovereignty. Therefore, there was no room for any debate at all on this issue.

argued that this means incarnation of a god; therefore, the Emperor could still be an arahitogami even without being an akitsumikami anymore.

88 In Marius B. Jansen, The Making of Modern Japan, The Belknap Press of Harvard University Press, Cambridge, 2000, p. 669.

89 (1) When it has become necessary in future to amend the provisions of the present Constitution, a project to that effect shall be submitted to the Imperial Diet by Imperial Order.

(2) In the above case, neither House can open the debate, unless not less than two thirds of the whole number of Members are present, and no amendment can be passed, unless a majority of not less than two thirds of the Members present is obtained.

90 On the drafting procedure and the complex phases that led the GHQ to directly write the text, there is a vast literature. See Charles Monnier, Les Américains et Sa Majesté l'Empereur. Etude du conflict cutlturel d'où naquit la Constitution japonaise de 1946, Editions de la Bacconnière, Neuchâtel, 1967; Alfred C. Oppler, Legal Reform in Occupied Japan: A Participant Looks Back, Princeton University Press, Princeton, 1976; Charles L. Kades, "The American Role in Revising Japan's Imperial Constitution”, Political Science Quarterly, vol. 104, n² 2, 1989, pp. 215-247; Koseki Shōichi, The Birth of Japan's Postwar Constitution, Westview Press, Boulder, 1997; Dale M. Hellegers, We, the Japanese People: World War II and the Origins of the Japanese Constitution, op. cit.; Lawrence Beer and John M. Maki, From Imperial Myth to Democracy: Japan's Two Constitutions, 1889-2002, op. cit.

91 A significant part of the Japanese constitutional scholars contested the imposed nature of the new Constitution, claiming that it was the result of a collaboration (collaborative theory) and thus not an imposed constitution oshitsuke Kenpō (押し付け憲法). As a proof, there is the fact that the Constitution has never been amended. See Takayanagi Kenzō, "Some Reminiscences of Japan's Commission on the Constitution", in Dan Fenno Henderson (ed.), The Constitution of Japan: Its First Twenty Years, 1947-1967, University of Washington Press, Seattle, 1968, pp. 71-73 and pp. $76-88$. 
The GHQ was not quite sure on the new legal status of the Emperor, beside the fact that he could not have been the sovereign anymore and that all the evil that came from the Meiji Constitution was that the imperial powers - exercised either directly by him or in his name - had no effective counterbalance nor check. Moreover, since the aim was to completely dismantle the tennossei, the new Constitution could have not qualified anymore the Emperor as sacred and inviolable.

All these changes were considered to be completely unacceptable for the Japanese government and for the majority of the pre-war establishment, which was still in charge. ${ }^{92}$ It is important to outline the fact that the two-year period 1945-1946 witnessed a widespread participation to the drafting of the new Constitution, in the sense that a variety of so-called private drafs was proposed to the government. ${ }^{93}$ Basically all these drafts were characterized by a stronger commitment (with respect to the one shown by the government) toward the establishment of a democratic government and by the awareness that the revision of the imperial system was a necessary step (far less the complete exclusion of the Emperor from the sovereign power). Some of these drafts even proposed the abolition of the imperial institution, such as Takano Iwasaburō's Outline of a Constitution for the Japanese Republic. Not even the one proposed by the Socialist Party went that far! The Socialist Party's Outline for New Constitution provided for the sovereignty belonging to the State, where the State had to be interpreted as a cooperative body composed by the people and the Emperor and for the governing power to be assigned mainly to the Diet and in a small part also to the Emperor. Other drafts, such as the one of the Constitution Discussion Society, provided for the joint sovereignty of the people and the Emperor.

The drafting debate was thus very lively, with different opinions and proposals on the role of the Emperor discussed by the civil society, the academia, the government and the SCAP. However, what emerged from this constituent moment was a great unbalance in the importance that was given to the sections of the Meiji Constitution that had to be amended (i.e. the entire Meiji Constitution) and the incapability of the government to accept those amendments. In so doing, the government missed his chance to be actually an active part in the writing of the new text, continuing to be anchored to the old imperial principles. ${ }^{94}$ Therefore, the paradox was that, despite for the Japanese government the chapter devoted to the Emperor was of utmost importance, for the GHQ it did not presented any particular nor delicate problem. Therefore in charge of the drafting of the chapter was leftover personnel, ${ }^{95}$ in the persons of Richard A. Poole and George A. Nelson. 96

92 The U.S. heavily relied on the efficient Japanese bureaucracy, which was thus not purged.

93 An overview of all these drafts is in Koseki Shōichi, The Birth of Japan's Postwar Constitution, op. cit., pp. 26-49.

94 Surely, this goes manly for what concerns the Emperor, but not exclusively. The conservative approach involved the whole text of the Constitution.

95 Dale M. Hellegers, We, the Japanese People: World War II and the Origins of the Japanese Constitution, Tōkyō, vol. 2, op. cit., p. 560.

96 Neither of them had qualifications for the job assigned; they were in their twenties with almost no legal education and a little knowledge of Japan. 
The orders were clear: strict delimitation of the powers of the Emperor and absolute clarification of his merely decorative role. In MacArthur's entourage there was the belief that it would have been possible to strike at the Emperor system - even abolishing him - without encountering a strong opposition from the Japanese people provided that the physical person of the Emperor were not touched.

However, Poole and Nelson, despite agreeing with the SCAP on the symbolic role of the Emperor, considered more advisable not to deprive too much the Throne of his role. Therefore, they moulded the Throne as the focal point for the nation's sense of self and its sentiment of national unity. Moreover, echoing Sieyès and the revolutionary philosophers, the Emperor would derive his position from the will of the nation.

Therefore, the Emperor was stripped of his sovereignty and he is qualified just as the symbol of the nation, not even as the head of State. This choice did not originated from a directive of the SCAP, since General MacArthur was not concerned about the Emperor qualified as the head of the State, as long as he had no actual power to exercise. The Emperor, according to MacArthur had to be entrusted powers that he had to exercise in accordance with the constitution.

When coming to the powers assigned to him by the new Constitution, there was no unanimity of opinion within the SCAP's entourage; rather, it seemed that the majority was in favour of stripping the Emperor also of any power whatsoever. However, things ended up differently, more in line with Poole and Nelson's approach and thus he retained some powers, as the heads of State in a parliamentary executive.

The constitutional reform transformed the Emperor into a shōchō tennō (象徵 天皇), the symbol of the State and a sort of family man. ${ }^{97}$ However, the LDP98 governments have tried, and still are, to alter this perception of the Emperor's role that now has rooted in the Japanese society, in order to reaffirm the greatness of the country and to react to this Constitution that, by the ruling block, continues to be perceived as non-Japanese ${ }^{99}$ and dictated by a foreign power.

97 Watanabe Osamu, "The Emperor as a "Symbol" in Postwar Japan", The Emperor System in Modern Japan. Acta Asiatica, No. 59, 1990, pp. 110-131.

98 Liberal Democratic Party-Jiyūminshutō (自由民主党), shortened Jimintō (自民党). This is the ruling party (a part from 1993-1994 and 2009-2012) since its foundation in 1955.

99 The ruling block's claims of non-Japaneseness are based on an ideological perspective, since the values conveyed are considered to be non-Japanese. Considering the popularity that the Constitution still enjoys, these claims should be dismissed. This is not to deny the innovative and revolutionary character of the present-day Constitution. For sure, the claims of non-Japaneseness are well grounded when considering the language that does not sound Japanese at all. The reason here lays in the fact that the Constitution originally was written in English and later translated into Japanese. Therefore, the Japanese version is a translation. This remains even though the government tried to Japanise the text. To Japanise the text does not mean to simply translate it, rather to try to alter the meaning of the original text by using more ambiguous Japanese words in order to lead to an interpretation closer to the traditional Japanese values. The Japanisation was successful in very specific articles (such as Article 14). Article 14 enshrines the principle of equality; the English “all of the people" has been translated into Japanese as kokumin (国民), which literally means nationals. In doing so, the Japanese government narrowed the scope of the article, thus excluding foreign nationals. Only in 1978, with a landmark decision of the Supreme Court (McLean v Justice Minister, Minshü 32-7-1223, 4th October 1978) the enjoyment of the rights 
Since the government lost the battle on the constitutional amendment and had to accept the new sovereignty principle and the symbolic role of the Emperor, he tried to preserve what was left of the old kokutai in the Criminal Code that still provided for crimes against the Imperial House, namely high treason (Articles73 and 75) and lèse majesté (Articles 74 and 76). The strong defence that the government made of these provisions was due to the alleged necessary protection of the tranquillity of the nation, since the Emperor, according to the words of the then Prime Minister Yoshida "is the centre of national veneration", 100 thus not being an ordinary individual. MacArthur did not accept such an argument, outlining that since now the Emperor was the symbol of the State, he did not deserve "no more and no less legal protection than that accorded to all other citizens of Japan". ${ }^{101}$ Even though the new Constitution was already entered into force, the ruling class still showed her commitment to the principles of the Meiji Constitution.

This second transplant was more invasive, since it was performed against the government (but less against the public opinion) and affected more substantially the core elements of the Japanese tradition. However, as happened during the Meiji Era, the tradition was remodeled in order to adapt it to the changed legal and political scenario and to better serve the imperial institution itself.

\section{CONCLUSION: AN EMPEROR FOR THE TWENTY-FIRST CENTURY}

The new role for the new Emperor has been a great success. The Japanese people, in particular when difficulties strike the country, group around the Emperor, deriving from his role as the symbol of the nation the strength they need. While governments have usually a medium-low support rate, 102 the Emperor always enjoys a widespread support, the Japanese people being sympathetic towards him and his family.

Nevertheless, despite the new imperial role does not rise concerns, the tradition is still highly influencing the perception of the imperial institution by the society and his sacred aura remains. The present-day debate on the abdication of the Emperor - which is not provided for neither by the Constitution nor by the Imperial Household Law - is emblematic. ${ }^{103}$

and freedoms was extended to foreign nationals too. The preamble, in particular, does not sound Japanese at all. See Inoue Kyoko, MacArthur's Japanese Constitution: A Linguistic and Cultural Study of Its Making, The University of Chicago Press, Chicago, 1991.

100 Koseki Shōichi, The Birth of Japan's Postwar Constitution, op. cit., p. 229.

${ }^{101}$ Koseki Shōichi, The Birth of Japan's Postwar Constitution, op. cit., p. 230.

102 In spite of this, Japanese politics is characterised by immobilism and conformism, mainly for social reasons. A powerful work on Japanese society is still R. Benedict, The Chrysanthemum Ruth and the Sword, Houghton Mifflin, Boston, 1946. The book was commissioned by the U.S. Office of War Information, in order to understand and predict the behaviour of the Japanese in the Second World War.

103 On the $8^{\text {th }}$ August 2016, the Emperor broadcasted a message where he addressed the Japanese people, expressing his growing difficulties to perform his constitutional duties due to his aging, outlining that it is important for an Emperor to be on the same page as the society, which is more and more difficult when aging. However, the Emperor never pronounced the word 
While the public opinion is supportive of the hypothesis of an imperial abdication, the government is against it. Despite all monarchs have the right to abdicate (even the Pope!), denying this possibility to the Japanese Emperor it as stating loud and clear that he is not a monarch like the others.

The issues of the name of the era ${ }^{104}$, of the status of the retired Emperor ${ }^{105}$ and the claim that introducing abdication in the Imperial Household Law could foster instability and uncertainty and may even raise the possibility of a monarch being pushed to abdicate under political pressure, cannot be dismissed. Nevertheless, they seem to express more the will of maintaining the Emperor as a non-ordinary institution rather than the result of a well-grounded concern on the viability of the reform. Therefore, the government advocates no amendment of the Imperial Household Law, thus maintaining the sole posthumous succession, and favours the enactment of a special legislation. However, this option is not free of constitutional concerns, since at Article 2 the Constitution provides for a succession to the Throne in accordance with the Imperial House Law passed by the Diet and not with any special legislation passed by the Diet. Nonetheless, the government went for the latter option and the Diet, on 9 $9^{\text {th }}$ June 2017, passed the special legislation, allowing the first imperial abdication since 1817 Emperor Kokaku's and the first under the present day Constitution. An ordinance issued by the Government set the abdication on 30th April 2019 and Crown Prince Naruhito will ascend to the throne the following day. While the enthronement ceremony is scheduled to take place on $2^{\text {nd }}$ October 2019 , marking the formal end of the transition period. The new era name should be announce on $1^{\text {st }}$ April 2019.

The conservative view of the LDP government on the issue reflects an oldfashioned approach to the imperial institution, which is not shared by the people. It is possible to perceive this detachment also between the Emperor and government. Despite the Emperor has always been respectful of his constitutional duties, it is possible to derive from his attitude and few declarations his commitment toward peace (threatened by the new security bills and by the possibility of amendment of the pacifist Article 9) and the Constitution.

In the millennial history of Japan, the imperial institution has proved to overcome every possible challenge and has played all the possible roles. From an almost irrelevant figure during the Shogunate, to the all-powerful (more in theory

abdication (tai'i-退位). The Japanese people were very sympathetic with the Emperor, the government far less.

104 The Japanese calendar system is based on the era system (gengo-元号), consisting of two elements, the first being the proper name of the era and the second a number, counting the years since the era began. There is no year zero and it is possible that two different gengo co-exist in the same year. This system derives from the Chinese tradition. Since the Meiji Era, the principle of one reign, one era name (issei ichigen-一世一元) was adopted. The era name is used as a posthumous name of the Emperor. Since the 1979 Name Era Law, it is among the cabinet powers to designate eras (previously the choice was up to the Emperor). The system creates problems when the era changes, since it requires a workload of computer programmers and engineers, and may create general confusion. This is why the government uses this as a disadvantage of allowing abdication. However, it does not seem a strong point for two main reasons: the first being that the cabinet is likely already to be working on the new era name, and second that the very same problems are caused by the natural death of the Emperor.

105 We refer to status generally speaking. The title to be addressed, the residence, the staff, the role of the retired Emperor are all issue that have to be considered. 
that in reality) living-god of the Meiji Era and of the tennōsei fashizumu, to the peaceful symbol of a new democratic nation. The Western legal thought has played a fundamental role in moulding the Meiji and the present Emperor, trying to respect the tradition as much as possible. Besides, when the tradition was not supportive, a new tradition was introduced.

The German influence played a major influence with respect to the American one, despite less revolutionary. The Meiji drafting phase was much more elaborated and thoughtful. In 1945-1946 the political situation did not allowed neither years to elaborate on the kokutai nor the possibility not to alter the kokutai. It was in this moment, in the drafting phase of the new Constitution, to which the SCAP urged the civil society to participate, that the gap between the ruling block and the civil society on the conception and on the interpretation of the role of the Emperor originated.

To conclude, just to qualify the Japanese Emperor as the symbol of the nation would mean to underestimate what he really is, beyond the wording of the Constitution. Despite not being neither the titular of the sovereign power nor a living god, he still is the heart of the nation, the core pillar that sustains the Japanese people and the living proof of the ability of the country to overcome any challenge.

Enviado el (Submission Date): 1/03/2018

Aceptado el (Acceptance Date): 23/04/2018 